\title{
Performance, Carcass Percentage, and Production Cost for Awassi Lambs Fed High Energy Diet for Short Fattening Period
}

\author{
Mysaa Ata ${ }^{1}$, Fatima Al-Lataifeh ${ }^{1} \&$ Mohammad Altarawneh ${ }^{2}$ \\ ${ }^{1}$ Department of Animal Production and Protection, Faculty of Agriculture, Jerash University, Jerash, Jordan \\ ${ }^{2}$ Department of Agricultural Economics and Extension, Faculty of Agriculture, Jerash University, Jerash, Jordan \\ Correspondence: Mysaa Ata, Department of Animal Production and Protection, Faculty of Agriculture, Jerash \\ University, Jerash 26150, Jordan. E-mail: mysaata@gmail.com; m.atta@jpu.edu.jo
}

Received: June 17, 2017

doi:10.5539/jas.v9n9p108
Accepted: July 18, $2017 \quad$ Online Published: August 15, 2017

URL: https://doi.org/10.5539/jas.v9n9p108

\begin{abstract}
An experiment was conducted to indicate the effect of feeding high energy diet for 45 days on male and female Awassi lambs' performance, carcass percentage, and cost of production. A total of twenty four Awassi lambs (12 males, and 12 females) averaging $18.2 \pm 0.70 \mathrm{~kg}$ body weight were used. Lambs were assigned randomly to two different groups (groups A and B); each group had twelve lambs (6 males and 6 females) and fed two different diets (low energy diet and high energy diet). Feed intake, total gain, average daily gain and feed conversion ratio was calculated and body measurements (height and length) were recorded. Lambs were slaughtered at the end of experiment, to evaluate carcass percentage. Cost of production was calculated based on ingredients' price at the time of the experiment. Final body weight, weight gain, and average daily gain were greater $(\mathrm{p}<0.05)$; while feed conversion ratio was lower $(\mathrm{p}<0.05)$ for lambs fed high energy diet than lambs fed low energy diet. Body length differences measured to be greater $(p<0.05)$ for male lambs fed high energy diet than other lambs. Fasted weight, hot carcass weight, and dressing percentage were higher $(\mathrm{p}<0.05)$ for lambs fed the high energy diet. Cost of gain was lower $(\mathrm{p}<0.05)$ for lambs in group B compared to lambs in group A. Therefore, the economical efficiency in this experiment was greater for lambs fed high energy diet than lambs fed the control diet during 45 days fattening period.
\end{abstract}

Keywords: Awassi lambs, body length, economical efficiency, high energy diet, hot carcass weight, performance

\section{Introduction}

Small ruminants, mainly sheep, are growing in importance for animal production. The proper body growth and development of growing lambs depends largely on the animal's level of nutrition. One of the major limitations of sheep production in Jordan is the inadequate availability of feedstuffs and lacking of natural pastures (Awawdeh, 2011). Natural pastures are available only in limited times of the year with variable quantity and quality of protein and energy contents (Awawdeh \& Obeidat, 2011). Moreover, Jordan considered as an arid and semi- arid country, with low annual rainfall that affects pastures development. On the other hand, extensive grazing by animals reduces pastures availability (Ghanem, 2013). Natural pastures are mostly low in energy and proteins and usually do not meet nutrients requirements for livestock (Salem \& Nefzaoui, 2003). The main principle in intensive lamb fattening process is concerned with the use of intensive feed ingredients in order to increase the rate of growth and development. Energy is a major dietary element which is responsible for the different utilization of nutrients and thereby enhances animal productivity and gain (Hosseini et al., 2008). Grains are the most common feedstuff used in finishing lambs. In Jordan, grains are commonly imported with high prices. As reported by the Ministry of Agriculture, Jordan imported about 71, 76, and 35 million tons of corn, barley, and soybean meal, respectively (Ministry of Agriculture, Annual Report, 2015). Other factors that limit sheep production in Jordan, other than insufficient local production of grains (Awawdeh et al., 2009) are harsh climate conditions, reduced governmental support to farmers (Obeidat \& Gharaybeh, 2011), and an increasing demands for humans to grains. Moreover, high feeding cost is another issue to be considered and a major part of production cost in sheep industry (Obeidat et al., 2011). While most of the fattening trials performed with lambs for reaching marketing weight is taking more than 65 days (Sayed, 2009; Obeidat et al., 2011; Ata, 2016), the aim of this study was to indicate the effect of feeding high energy diet for 45 days on Awassi lambs' performance 
and carcass percentage. Moreover, evaluating production cost during the experimental period to help local farmers choosing the best diet with lower cost to be used for fattening lambs in a short period.

\section{Materials and Methods}

\subsection{Experimental Design, Animals, and Diets}

The experiment was conducted including a total of twenty four (12 males, and 12 females) Awassi lambs, averaging 3 months of age and $18.2 \pm 0.70 \mathrm{~kg}$ body weight. Lambs were reared in a local private farm near Jerash University. A $2 \times 2$ factorial design was used and lambs were assigned randomly to two different groups; each group had twelve lambs ( 6 males and 6 females) and fed two different diets. The diets were A (low energy diet) and B (high energy diet). The diets were iso-nitrogenous and formulated to have $15 \%$ crude protein (CP on DM basis; Rios-Rincon et al., 2014; Table 1). Feed was given at $1 \%$ of the body weight to each animal. Lambs offered the high energy diet (group B) were allowed to free grazing twice weekly at available pastures to obtain their roughage requirements; while lambs fed low energy diet (group A) offered a total mixed ration which contains roughage. Lambs from each group were housed individually in shaded pens $(1.5 \mathrm{~m} \times 0.75 \mathrm{~m})$, and fed twice daily for 45 days. Diets were mixed biweekly during the study. Feed offered and refusals were recorded to calculate feed intake, while body weight was recorded weekly. Total gain, average daily gain (ADG) and feed conversion ratio (FCR) was calculated at the end of the experiment. Body measurements (height and length) were recorded at the beginning and the end of the experiment. At the end of the experiment, after $18 \mathrm{~h}$ fasting, all lambs were slaughtered at 8 am by trained personnel according to a standard slaughter procedure (Abdullah et al., 1998) to evaluate carcass percentage. Fasting live weight was recorded before slaughter and hot carcass weight (HCW) was immediately recorded after slaughter. Dressing percentage was calculated as the hot carcass weight percentage of the fasted live weight. Following the AOAC (1990) standard procedures, rations samples were analyzed for their dry matter (DM), organic matter (OM), and crude protein (CP; Table 1). The methods were as follows: DM $\left(100{ }^{\circ} \mathrm{C}\right.$ in air-forced oven for $24 \mathrm{~h}$; method 967.03$), \mathrm{OM}\left(550{ }^{\circ} \mathrm{C}\right.$ in ashing furnace for $6 \mathrm{~h}$; method 942), and CP by using (Kjeldahl procedure; method 976.06).

\subsection{Statistical Methods}

Data were analyzed using PROC MIXED of SAS (version 9.0, SAS Institute, Inc. Cary, NC, USA) with lamb considered the experimental unit using diets $\times$ gender effects. The mean separation was performed using t-test. The interaction means were reported as least square means by using Tukey test, and differences were referred to those having a $P \leq 0.05$.

Table 1. Ingredients of the experimental diets fed to Awassi lambs

\begin{tabular}{|c|c|c|}
\hline \multirow{2}{*}{ Item } & \multicolumn{2}{|c|}{ Diets $^{1}$} \\
\hline & $\mathrm{A}$ & B \\
\hline \multicolumn{3}{|l|}{ Ingredient (\% of the diet) } \\
\hline Corn grains & 0.0 & 22.0 \\
\hline Barley grain & 52.0 & 60.0 \\
\hline Soybean meal & 20.0 & 15.0 \\
\hline Wheat straw & 25.0 & 0.0 \\
\hline Salt & 1.4 & 1.4 \\
\hline Limestone & 1.5 & 1.5 \\
\hline Mineral and Vitamins ${ }^{2}$ & 0.1 & 0.1 \\
\hline \multicolumn{3}{|l|}{ Nutrient, $\%$ of $D M$} \\
\hline DM & 97.2 & 96.8 \\
\hline $\mathrm{OM}$ & 91.2 & 90.4 \\
\hline $\mathrm{CP}$ & 15.1 & 14.9 \\
\hline $\mathrm{ME}^{3}(\mathrm{Mcal} / \mathrm{kg})$ & 2.20 & 2.70 \\
\hline
\end{tabular}

Note. ${ }^{1}$ Diets offered were low Energy Diet $=$ Control (A), or High Energy Diet (B) on DM basis.

${ }^{2}$ Composition per $1 \mathrm{~kg}$ contained (vitamin A, 8,000,000 IU; vitamin $\mathrm{D}_{3}, 1,5000,000 \mathrm{IU}$; vitamin E, $1000 \mathrm{IU}$; $\mathrm{Mn}$, $0.40 \mathrm{mg}$; Zn, $0.15 \mathrm{mg}$; Fe, $0.50 \mathrm{mg}$; $\mathrm{Cu}, 0.50 \mathrm{mg}$; and Co $0.01 \mathrm{mg}$ ).

$\mathrm{ME}^{3}$ : Metabolizable energy; calculated using NRC (2007). 


\section{Results}

The parameters measured reflecting lambs growth performance that was affected by feeding different diets is shown in Table 2. Lambs fed high energy diet (group B) had greater $(\mathrm{p}<0.05)$ final body weight than lambs in group A with $32.1 \mathrm{~kg}$ for males and $30.6 \mathrm{~kg}$ for females fed high energy diet, while it was $28.8 \mathrm{~kg}$ for male and $26.8 \mathrm{~kg}$ for female lambs fed the control diet. Total gain was significantly higher $(\mathrm{p}<0.05)$ for lambs in group B with $13.2 \mathrm{~kg}$ for females and $13.1 \mathrm{~kg}$ for males than female $8.68 \mathrm{~kg}$ and male $10.5 \mathrm{~kg}$ lambs in group A. Lambs feed intake was not affected $(p>0.05)$ by the different diets and gender. Average daily gain (ADG) was greater $(p<0.05)$ for male and female lambs fed the high energy diet compared to male and female lambs fed low energy diet. Feed conversion ratio (FCR) was greater $(p<0.05)$ for female lambs fed the low energy diet than other lambs fed the different experimental diets.

Table 2. Performance of Awassi lambs fed the different diets

\begin{tabular}{|c|c|c|c|c|c|c|}
\hline \multirow{3}{*}{ Item $^{2}$} & \multicolumn{4}{|c|}{ Diets $^{1}$} & \multirow{3}{*}{ SEM } & \multirow{3}{*}{$\mathrm{P}_{\text {value }}{ }^{3}$} \\
\hline & \multicolumn{2}{|c|}{$\mathrm{A}$} & \multicolumn{2}{|c|}{ B } & & \\
\hline & Male & Female & Male & Female & & \\
\hline Initial BW (kg) & 18.3 & 18.1 & 18.9 & 17.4 & 0.45 & 0.15 \\
\hline Final BW (kg) & $28.8^{b}$ & $26.8^{b}$ & $32.1^{\mathrm{a}}$ & $30.6^{\mathrm{a}}$ & 0.73 & 0.02 \\
\hline Total Gain (kg) & $10.5^{b}$ & $8.68^{c}$ & $13.1^{\mathrm{a}}$ & $13.2^{\mathrm{a}}$ & 0.74 & 0.00 \\
\hline Feed Intake (g) & 960 & 945 & 925 & 976 & 0.03 & 0.25 \\
\hline $\mathrm{ADG}(\mathrm{g})$ & $233^{b}$ & $193^{c}$ & $290^{\mathrm{a}}$ & $294^{\mathrm{a}}$ & 0.01 & 0.00 \\
\hline FCR & $4.12^{b}$ & $4.95^{\mathrm{a}}$ & $3.19^{\mathrm{c}}$ & $3.33^{\mathrm{c}}$ & 0.17 & 0.00 \\
\hline
\end{tabular}

Note. ${ }^{1}$ Diets offered were low Energy Diet $=$ Control (A), or High Energy Diet (B) on DM basis.

${ }^{2} \mathrm{BW}=$ Body Weight, Gain $=$ Final BW - Initial BW, ADG (Average daily gain) $=$ Gain $/ 45$ days, FCR $($ Feed conversion ratio) $=$ Intake/ADG.

${ }^{3}$ Means for the interaction between diets and gender having different superscripts within a row are statistically significant $(\mathrm{p}<0.05)$.

Body measurements were recorded at the beginning and the end of the experimental period as shown in Table 3 . There were no significant differences $(\mathrm{p}>0.05)$ in body height and length for lambs fed the different diets in both groups except for males in group B. Body length difference measured to be greater $(p<0.05)$ for male lambs fed the high energy diet and was $16.7 \mathrm{~cm}$ compared to female lambs in the same diet group $(13.2 \mathrm{~cm})$ and other male and female lambs fed low energy diet $(13.2 \mathrm{~cm}$ and $13.5 \mathrm{~cm}$, respectively).

Table 3. Body measurements of Awassi lambs fed the different diets

\begin{tabular}{|c|c|c|c|c|c|c|}
\hline \multirow{3}{*}{ Item $^{2}$} & \multicolumn{4}{|c|}{ Diets $^{1}$} & \multirow{3}{*}{ SEM } & \multirow{3}{*}{$\mathrm{P}_{\text {value }}{ }^{3}$} \\
\hline & \multicolumn{2}{|c|}{$\mathrm{A}$} & \multicolumn{2}{|c|}{$\mathrm{B}$} & & \\
\hline & Male & Female & Male & Female & & \\
\hline Initial Body Height $(\mathrm{cm})$ & 51.5 & 51.2 & 51.0 & 51.3 & 1.44 & 0.74 \\
\hline Final Body Height (cm) & 60.7 & 60.5 & 61.0 & 62.2 & 1.01 & 0.53 \\
\hline Height Difference $(\mathrm{cm})$ & 9.20 & 9.30 & 10.0 & 10.8 & 0.58 & 0.57 \\
\hline Initial Body Length $(\mathrm{cm})$ & 66.2 & 63.7 & 64.8 & 65.3 & 1.48 & 0.32 \\
\hline Final Body Length (cm) & 79.3 & 77.2 & 81.5 & 78.5 & 1.27 & 0.74 \\
\hline Length Difference (cm) & $13.2^{\mathrm{b}}$ & $13.5^{b}$ & $16.7^{\mathrm{a}}$ & $13.2^{\mathrm{b}}$ & 1.01 & 0.02 \\
\hline
\end{tabular}

Note. ${ }^{1}$ Diets offered were low Energy Diet $=$ Control (A), or High Energy Diet (B) on DM basis.

${ }^{2}$ Body height and length differences were calculated by subtracting the initial from the final measurements.

${ }^{3}$ Means for the interaction between diets and gender having different superscripts within a row are statistically significant $(\mathrm{p}<0.05)$. 
At the end of the experiment, lambs were slaughtered and carcass percentage was measured as shown in Table 4 . Fasted body weight was greater $(p<0.05)$ for lambs fed the high energy diet compared to lambs fed the control diet. Hot carcass weight was greater $(\mathrm{p}<0.05)$ for lambs in group B than lambs in group A. Dressing percentage was lower $(\mathrm{p}<0.05)$ in lambs fed the low energy diet compared to lambs fed the high energy diet $(46.4 \mathrm{~kg}$ and $46.6 \mathrm{~kg}$ for male and female lambs in group A, while $47.5 \mathrm{~kg}$ and $48.1 \mathrm{~kg}$ for male and female lambs in group B).

Table 4. Carcass percentage of Awassi lambs fed the different diets

\begin{tabular}{|c|c|c|c|c|c|c|}
\hline \multirow{3}{*}{ Item $^{2}$} & \multicolumn{4}{|c|}{ Diets $^{1}$} & \multirow{3}{*}{ SEM } & \multirow{3}{*}{$\mathrm{P}_{\text {value }}{ }^{3}$} \\
\hline & \multicolumn{2}{|r|}{$\mathrm{A}$} & \multicolumn{2}{|c|}{ B } & & \\
\hline & Male & Female & Male & Female & & \\
\hline Fasted Weight(kg) & $27.8^{b}$ & $25.6^{\mathrm{b}}$ & $30.9^{\mathrm{a}}$ & $29.4^{\mathrm{a}}$ & 0.73 & 0.00 \\
\hline $\mathrm{HCW}(\mathrm{kg})$ & $12.9^{b}$ & $11.9^{b}$ & $14.7^{\mathrm{a}}$ & $14.1^{\mathrm{a}}$ & 0.34 & 0.00 \\
\hline Dressing (\%) & $46.4^{\mathrm{b}}$ & $46.6^{\mathrm{b}}$ & $47.5^{\mathrm{a}}$ & $48.1^{\mathrm{a}}$ & 0.22 & 0.00 \\
\hline
\end{tabular}

Note. ${ }^{1}$ Diets offered were low Energy Diet $=$ Control (A), or High Energy Diet (B) on DM basis.

${ }^{2} \mathrm{HCW}=$ Hot Carcass Weight, Dressing $\%=$ Dressing percentage was calculated as the hot-carcass weight percentage of the fasted live weight.

${ }^{3}$ Means for the interaction between diets and gender having different superscripts within a row are statistically significant $(\mathrm{p}<0.05)$.

Cost of feed used in this experiment was calculated as presented in Table 5. Cost of formulating the low energy diet was higher (the price of hey straw added to the diet increased the total cost) and it was 336.48 US \$/Ton, while it was 312.22 US $\$$ /Ton for the high energy diet (the diet did not contain hay straw). Cost of feed consumed was similar $(\mathrm{p}=0.95)$ in lambs fed the different experimental diets. Cost of gain (cost of Kg's of feed that was consumed by lambs during the 45 days divided by lambs total gain at the same period) was lower ( $\mathrm{p}<$ 0.05 ) in lambs fed the high energy diet (Group B) than lambs fed the low energy diet (group A).

Table 5. Feed cost of Awassi lambs fed the different diets

\begin{tabular}{|c|c|c|c|c|}
\hline \multirow{2}{*}{ Item } & \multicolumn{2}{|c|}{ Diets $^{1}$} & \multirow{2}{*}{ SEM } & \multirow{2}{*}{$P_{\text {value }}^{5}$} \\
\hline & A & $\mathrm{B}$ & & \\
\hline Cost of Feed (US \$/Ton) $)^{2}$ & 336.48 & 312.22 & & \\
\hline Cost of Feed Consumed (US $\$ / \mathrm{Kg})^{3}$ & 0.32 & 0.33 & 0.02 & 0.95 \\
\hline Cost of Gain (US $\$ / K g)^{4}$ & $1.57^{\mathrm{a}}$ & $1.10^{\mathrm{b}}$ & 0.08 & 0.00 \\
\hline
\end{tabular}

Note. ${ }^{1}$ Diets offered were low Energy Diet $=$ Control (A), or High Energy Diet (B) on DM basis.

${ }^{2}$ Calculated based on ingredients' price at the time of the experiment (May, 2017).

${ }^{3}$ Cost of Feed consumed $=$ Cost of Feed intake in $\mathrm{Kg} / \mathrm{Lamb}$.

${ }^{4}$ Cost of gain $=$ cost of intake of lamb during the 45-day study/total gain in $\mathrm{kg}$.

${ }^{5}$ Means having different superscripts within a row are statistically significant $(\mathrm{p}<0.05)$.

\section{Discussion}

A study was performed to indicate the effect of feeding high energy diet for 45 days fattening period on male and female Awassi lambs performance, carcass traits, and feeding cost per kg gained. As shown in Table 2, final weight, total gain, and ADG were enhanced by high energy diet fed to male and female Awassi lambs. This result is consistent with that reported by others (Sayed, 2009; Hosseini et al., 2008; Yagoub \& Babiker, 2008). Rios-Rincon et al. (2014) reported that lambs fed high-energy diets for 84 days showed an increase in gain to feed ratio. Increasing feed efficiency has been a common response when comparing high-energy to low-energy diets (NRC, 2007; Sayed, 2009). However, the effect of increased dietary energy levels on ADG varies according to different energy levels. In this study, the enhancement of ADG during the 45 days experimental period might be due to the increase in energy level that allows the production of more fermentable ME for rumen 
microorganisms which leads to a rise in the microbial protein production and in the amount of protein available to the animal to grow. Feed conversion ratio (FCR) decreased in lambs fed the control diet (low energy diet) and that reflects the decrease in growth rate and live weight attained by those animals. This agreed with the findings by Ebrahimi et al. (2007) and Hosseini et al. (2008) who reported similar results but with longer fattening period (around 90 days fattening period).

Body measurement was not affected by the different diets except for body length differences (Table 3 ). The average changes in length between lambs fed high energy diet compared to lambs fed the control diet might be due to better utilization of the feed during the experimental period. The results of this study are in agreement with Bassano et al. (2003) results. The researchers also found a relationship between weight and body measurements which changed mainly by the effect of sex and season.

Fasted weight, HCW and Dressing percentage were increased with lambs fed the high energy diet than the low energy diet (Table 4). The increase in fasting weight and HCW reflects the increase in final weight gained by lambs fed the high energy diet for 45 days. Jabbar and Anjum (2008) reported similar results; they found that lambs fed high concentrate diet for 66 days had greater $(\mathrm{p}<0.05)$ dressing percentage than lambs fed high forage diet. Moreover, Mahgoub et al. (2000) studied the effects of dietary energy density on carcass chemical composition of Omani lambs and found that meat production was improved in the form of higher body weight gains and better carcass composition by increasing energy levels in the diet. On the other hand, it was reported by Rios-Rincon et al. (2014) that the energy level in high-energy finishing diets had small effects on HCW and dressing percentage, while an increase in visceral fat as a result of increasing the energy density of the diet was attained.

Feed cost was higher for the control diet (336.48 US \$/Ton) compared to the high energy diet (312.22 US \$/Ton) as illustrated in Table 5. Total cost of feed consumed was similar between the different diets. However, cost of feed per kg weight gain decreased with increasing energy level. Lambs fed the low energy diet had high cost of gain due to the fact that animals on that treatment had lower live weight gain during the experimental period. Cost of gain was lower for lambs fed the high energy diet which indicates that this diet was most economical for fattening sheep in this experiment.

\section{Conclusion}

The economical efficiency in this experiment was greater for lambs fed high energy diet than lambs fed the low energy diet during the 45 days fattening period. It could be concluded that increasing energy level in lamb's diet for a short fattening period resulted in increasing growth performance, body length measurements, carcass percentage, and reduces cost of gain of Awassi lambs.

\section{References}

Abdullah, A. Y., Purchas, R. W., \& Davies, A. S. (1998). Patterns of change with growth for muscularity and other composition characteristics of Southdown rams selected for high and low back depth. New Zealandm Jornal of Agriculture Research, 41, 367-376. https://doi.org/10.1080/00288233.1998.9513321

AOAC. (1990). Offical Methods of Analysis (15th ed.). Association analatycal chemist, Arlington, VA.

Ata, M. (2016). Effect of hydroponic barley fodder on Awassi lambs performance. Journal of Biology, Agriculture and Healthcare, 6(8), 60-64. http://doi.org/10.1136/inpract.11.5.211

Awawdeh, M. S. (2011). Alternative feedstuffs and their effects on performance of Awassi sheep: A review. Tropical Animal Health and Production, 43, 1297-1309. http://dx.doi.org/10.1007/s11250-011-9851-z

Awawdeh, M., \& Obeidat, B. (2011). Effect of supplemental exogenous enzymes on performance of finishing Awassi lambs fed olive cake-containing diets. Livestock Science, 138, 20-24. https://doi.org/10.1016/ j.livsci.2010.11.021

Awawdeh, M., Obeidat, B., Abdullah, A., \& Hananeh, W. (2009). Effects of yellow grease or soybean oil on performance, nutrient digestibility and carcass characteristics of finishing Awassi lambs. Animal Feed Science and Technology, 153, 216-227. https://doi.org/10.1016/j.anifeedsci.2009.06.013

Bassano, B., Bergero, D., \& Peracino, A. (2003). Accuracy of body weight prediction in Alpine ibex (Capra ibex L. 1758) using morphometry. Journal Animal Physiology and Animal Nutrition, 87(3-4), 79-85. https://doi.org/10.1046/j.1439-0396.2003.00418.x

Ebrahimi, R., Ahmadi, H. R., Zamiri, M. J., \& Roqhani, E. (2007). Effect of energy and protein levels on feedlot performance and carcass characteristics of Mehraban ram lambs. Pakistan Journal of Biological. Scince, 15(10), 1679-1684. https://doi.org/10.3923/pjbs.2007.1679.1684 
Ghanem, A. A. (2013). Case study: Trends and early prediction of rainfall in Jordan. American Journal of Climate Change, 2, 203-208. https://doi.org/10.4236/ajcc.2013.23021

Hosseini, S. M., Akbary, S. M., Maheri-Sis, N., \& Aghsaghali, A. M. (2008). Effect of different energy levels of diet on feed efficiency, growth rate and carcass characteristics of fattening Bahmaei lambs. Journal of Animal \& Veterinary Advance, 7(12), 1551-1554. Retrieved from http://medwelljournals.com/ abstract/?doi=javaa.2008.1551.1554

Jabbar, M. A., \& Anjum, M. I. (2008). Effect of diets with different forage to concentrate ratio for fattening of Lohi lambs. Pakistan Veterinary Journal, 28(3), 150-152.

Mahgoub, O., Lu, C. D., \& Early, I. R. J. (2000). Effects of dietary energy density on feed intake, body weight gain and carcass chemical composition of Omani growing lambs. Small Ruminant Research, 37(1-2), 35-42. https://doi.org/10.1016/S0921-4488(99)00132-7

Ministry of Agriculture. (2015). The Annual Report of the Animal Production Department. Ministry of Agriculture, Amman, Jordan.

NRC. (2007). Nutrient Requirement of Sheep and Goats (6th ed.). National Academy of Sciences, Washington, DC, USA.

Obeidat, B. S., \& Gharaybeh, F. F. (2011). Effect of feeding sesame hull on growth performance, nutrient digestibility, and carcass characteristics of Black goat kids. Asian-Australasian Journal of Animal Sciences, 24, 206-213. https://doi.org/10.5713/ajas.2011.10107

Obeidat, B., Alrababah, M., Abdullah, A., Alhamad, M., Gharaibeh, M., Rababah, T., \& Ishmais, M. A. (2011). Growth performance and carcass characteristics of Awassi lambs fed diets containing carob pods (Ceratonia siliqua L.). Small Ruminant Research, 96, 149-154. https://doi.org/10.1016/j.smallrumres.2010.12.001

Rios-Rincon, F. G., Estrada-Angulo, A., Plascencia, A., Lopez-Soto, M. A., Castro-Perez, B. I., Portillo-Loera, J. J., ... Davila-Ramos, H. (2014). Influence of protein and energy level in finishing diets for feedlot hair lambs: Growth performance, dietary energetic and carcass characteristics. Asian Australian Journal of Animal Science, 27(1), 55-61. https://doi.org/10.5713/ajas.2013.13307

Salem, H. B., \& Nefzaoui, A. (2003). Feed blocks as alternative supplements for sheep and goats. Small Ruminant Research, 49, 275-288. https://doi.org/10.1016/S0921-4488(03)00144-5

SAS. (2000). SAS user's guide: Statistics version (9th ed.). SAS Institute, Inc. Cary, NC, USA.

Sayed, A. N. (2009). Effect of different dietary energy levels on the performance and nutrient digestibility of lambs. Veterinary World, 2(11), 418-420.

Yagoub, Y. M., \& Babiker, S. A. (2008). Effect of dietary energy level on growth and carcass characteristics of female goats in Sudan. Journal of Animal Science, 80, 100-115. Retrieved from http://www.lrrd.org/ lrrd20/12/yago20202.htm

\section{Copyrights}

Copyright for this article is retained by the author(s), with first publication rights granted to the journal.

This is an open-access article distributed under the terms and conditions of the Creative Commons Attribution license (http://creativecommons.org/licenses/by/4.0/). 